\title{
FINANCIAL REPORTING OF LISTED COMPANIES ON THE STOCK EXCHANGES IN EUROPEAN UNION AND SOUTHEAST EUROPE
}

\author{
Zoran Jeremić, Ivica Terzić \\ Faculty of Busines in Belgrade, Singidunum University, Belgrade, Serbia,
}

\begin{abstract}
:
This paper deals with the listing requirements for admission on the one of the stock exchanges in the European Union. EU regulations as well as accounting standards related to this field are specified in this paper. Particular attention is is dedicated to the state of the capital markets and financial reporting on stock exchanges in Southeast Europe, in order to determine the degree of compliance with EU legislation. We conducted research about the legislation and listed companies on the stock exchanges in the countries of the region, in order to perceive the position of the Serbian capital market and listed companies on the Belgrade Stock Exchange, compared to the region. At the and of paper we present recommendations for improvement in this area.
\end{abstract}

\section{Key words:}

listed companies, stock exchange, accounting standards.

\section{INTRODUCTION}

Company's going public and its transformation to a legal form of an open joint stock company has many benefits. In this way, company may increase its capital without further deepening its indebtedness which has favourable effect on debt to capital ratio. Issued shares can also be used for payment instead of cash or for taking over another company, whereas the shareholders can sell them on the stock exchange, if the market is liquid, and turn shares into cash. In addition to that, company has the opportunity to become more appealing to good management staff and to motivate its employees through stock options. Unlike developed markets, which take advantage, on a greater scale, of going public to accumulate additional capital, this is rather rare on underdeveloped markets and accompanied with many contradictions. The elementary problem lies in the socalled inefficient market i.e. low liquidity, small trading volume and poor overall investment climate. These economies are characterised by financial statements of poor quality and not so strict adherence to the principles of transparency and full disclosure of an issuer. All this affects the quality of the operations of the entire financial community which is composed of managers, analysts, institutional and individual investors. Therefore, it is of vital importance to improve the quality of the capital market and thus create conditions which are prerequisite for securities based financing. This is particularly important for the countries of Southeast Europe where the bank loans are predominant form of financing whereas financing through issue of shares, bonds and other financial instruments has been almost non-existent in the aftermath of the financial meltdown.

\section{FINANCIAL REPORTING BY LISTED COMPANIES}

Initial public offering i.e. company's going public, brings about significant changes. The company becomes open to all investors, which leads to certain changes in the relationship between the owners of capital and the management. The existing owner, or more owners, loses absolute control over the company to the extent of more or less dispersed ownership. A specific relationship arises between the management and company owners, which leads to what is in literature known as "agency problem" [1].

From the standpoint of financial reporting, the key requirement is to achieve full transparency in reporting and disclosure of all aspects of business operations to the public. Such disclosures ensure positive publicity if the business results of the company are positive, though it is associated with significant costs, start- ing from the costs of going public to the costs of reporting. In 2002, a co-called Sarbanes-Oxley Act was passed with the aim to protect the investors on the developed markets by increasing reporting requirements imposed on companies. However, this led to increase of costs incurred by companies going public which is, along with the increase in disclosure, contrary to the intent of this Act. The reporting requirements imposed on the companies operating on the underdeveloped markets are not so strict.

The company goes through various stages of growth and development from its foundation until its initial public offering. Each of these stages has a corresponding legal form, method of financing and management. Many companies started out as small-sized enterprises with a single founder or several partners. The initial capital was financed by means of their own funds, borrowings from acquaintances and relatives and startup loans. With the development of business operations, going public becomes a necessity for the company aiming to secure expansion capital. This development scenario, from a privately owned small-sized enterprise to a listed company, was observed in many large companies listed on the stock exchanges today. [2] Such was the beginning of many companies, from Coca-Cola to Microsoft, as well as Sony, GOOGLE, Apple, etc. Initial public offering (IPO), as means to boost the company growth, has so far been used mainly by the companies in US, but in the era of globalisation, other international companies have become more interested in this practice used by financial markets. (The best recent example is Chinese company: Alibaba - a global commerce company and the biggest rival to Amazon, which accumulated \$25 billion US in September 2014 through its initial public offering, followed by a $50 \%$ increase in the share price in two months, thus reaching the market value of $€ 250$ billion Euros.) [3].

\subsection{Initial Public Offering Process and Flow}

In order for a company to go public and be listed on the stock exchange, a series of preparatory actions need to be taken. All financial statements must be in compliance with the international accounting standards. After the Board of Directors approves the proposed initial public offering, the company's business books and financial statements for the past two to three years must be inspected. Any insider trading, compensation agreement and relationship involving management or $\mathrm{BoD}$, which are normal for privately owned company, but inappropriate for open joint stock company listed on the stock exchange, must be eliminated and the statements must be properly harmonised [4]. The next step requires for an investment banker and an accountant to initiate a 
comprehensive analysis of the company i.e. due diligence. Investment banker - underwriter must examine the current method of operation implemented by the management as well as business operations, financial standing, business performance, competitiveness and business plan of the company. Other factors are also analysed, such as: work force, suppliers, buyers, creditors and all other parties which have impact on the business operations of the company and may affect proper, truthful and adequate disclosure of its condition in the prospectus. Accounting company must examine the documents such as: contracts, payment orders and payment receipts in order to ensure accuracy and adequacy of financial statements presented to the investment public. Timing of the share issues and the terms and conditions of issues (most important of them being adequate share price) is of great importance for the success of the entire process. Following the completion of all preliminary actions regarding the preparation of financial statements and examination of company's business, the company and investment banking team are required to set up a series of meetings to present the company to potential investors and analysts. Accumulation of capital by means of IPO and subsequent recapitalisation through share issue prevailed in the expansion phase of the global economy from 2004 until its climax in 2007. The global economic crises resulted in huge drop in market capitalisation in 2008. With the recovery of the stock exchange market, the number of IPOs and listed companies which accumulate capital through new issues also increased, recording an upward trend in 2013 and 2014.

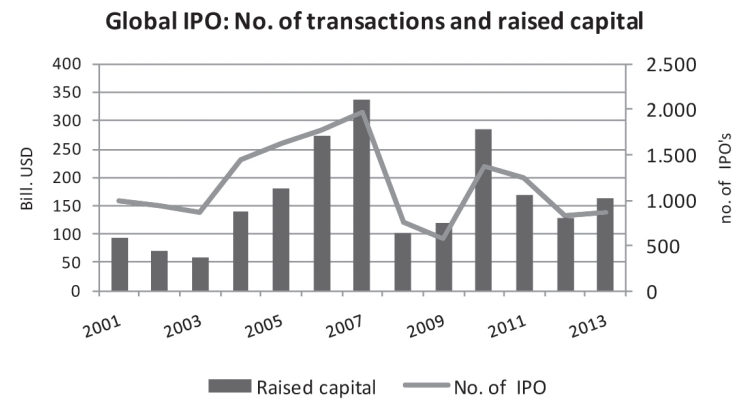

Figure 1: EY IPO Global trends Q4 2013.p.2

According to information made available by World Federation of Exchanges, market capitalisation of the stock exchanges around the world in 2013 amounted to \$64 trillion US which is a $17 \%$ increase since 2012 , with the highest growth recorded in Eurasian markets - 47\%. [5] This marks the two consecutive years of increase in market capitalisation following the dramatic drop caused by the global economic crisis.

\subsection{Reporting Standards for Companies Listed on the Stock Exchanges in EU}

Companies listed on the EU stock exchanges are subject to regulations which ensure high transparency. This is achieved by prescribing disclosure of financial information on the territory of EU countries in order to protect all market players: issuers, investors and shareholders. Directive on Transparency Requirements for Listed Companies [6] harmonises the obligations imposed on issuers of securities in order to protect all parties involved on the capital market. According to regulations applicable in EU, all companies listed on the stock exchanges must meet certain standards related to disclosure of financial statements and obligation to prepare financial statements in compliance with the International Accounting Standards (IAS) and International Financial Reporting Standards (IFRS). These obligations are imposed by the Directive on Application of International Accounting Standards, enacted in 2002 [7] which has been in effect since 2005 and Directive on Adoption of International Accounting Standards in accordance with this regulation, with an annex to Directive listing the adopted International Accounting Standards and International Financial Reporting Standards [8]. International Accounting Standards applicable in European Union and regulating transactions involving financial instruments are as follows: IAS 32: Presentation of Financial Instruments, IAS 33: Earnings per Share, IAS 39: Financial Instruments: Recognition and Measurement, and IFRS 2: Share-based Payment and IFRS 7: Financial Instruments: Disclosures.

The implementation of the said regulations, International Accounting Standards and International Financial Reporting Standards in the EU countries ensures high level of harmonisation between regulations and securities trading practices. Member states are obliged to incorporate these directives into their national legislations, with the possibility to broaden and define these regulations more closely, if needed. The other aim is to ensure convergence of the regulations and practices used in other capital markets across the world. Elementary requirements and principles contained in the said regulations are as follows:

Shareholders are treated equally, which is achieved through representation i.e. introduction of a "proxy", possibility of electronic voting and by reducing the threshold for notification of exceeding $5 \%$ of voting rights. In addition to existing so-called break-even points of $5 \%, 10 \%, 20 \%, 25 \%, 50 \%$ and $75 \%$, new thresholds i.e. break-even points were introduced: $15 \%$ and $30 \%$, whereas the deadline for notification is 5 business days. Disclosure is mandatory both on the web site of the issuing company and in the media. The issuer must publish its annual report no later than four months after the end of the fiscal year and must make it available for insight for another five years at the minimum. Annual financial statements must include Auditor's Report, Management Report and authorised persons' statement that they were prepared in compliance with the applicable international accounting standards.

Listed companies are also required to publish semi-annual reports and management reports disclosing the most important events affecting the business as well as the business projections for the next six months, accompanied with a comment and assessment regarding their impact on the future business results. If the semi-annual report is audited, it must be disclosed. Following the meeting of the General Assembly, the decisions must be posted on the web site, including decision on the distribution of dividends and new issues (if such decisions are reached). All decisions must be submitted to competent regulatory authority (securities committees or agencies), competent to inspect the implementation of such decisions and to verify their compliance with statutory requirements.

\subsection{Reporting by the Companies listed on the Stock Exchanges in Southeast Europe}

In order to understand the quality of reporting by the companies listed on the stock exchanges operating in the region, six stock exchanges from this region were analysed, three of which were in EU member states: Zagreb Stock Exchange (ZSE), Bulgarian Stock Exchange (BSE) and Ljubljana Stock Exchange (LSE) and three in the candidate countries: Belgrade Stock Exchange (BELEX), Macedonian Stock Exchange (MSE) and Montenegro Stock Exchange (MNSE). The starting point was the analysis of the regulations and criteria which the listed companies must comply with: division of regulated market into various market segments, requirements in respect of submission of financial statements, disclosure of significant events affecting stock price movement, market capitalisation and trading volume, market liquidity, share of stock exchange market capitalisation and trading volume in the GDP.

Even though stock exchanges in the EU member states have somewhat better performances, similar general limitations apply 


\begin{tabular}{lcccccccc}
\hline $\begin{array}{c}\text { Stock } \\
\text { Exchange }\end{array}$ & $\begin{array}{c}\text { No. of companies on regulated } \\
\text { market }\end{array}$ & $\begin{array}{c}\text { Market capitalisation } \\
\text { of regulated m. } \\
31.12 \text { 2013. }\end{array}$ & $\begin{array}{c}\text { value of trading in } \\
\text { 2013. }\end{array}$ & $\begin{array}{c}\text { GDP 2013 } \\
\text { (IMF) }\end{array}$ & $\begin{array}{c}\text { turnover/ } \\
\text { marketcap }\end{array}$ & $\begin{array}{c}\text { marketcap/ } \\
\text { GDP }\end{array}$ \\
\hline Beogradska & prime & standard & open & & in milions $€$ & 237 & 30.738 & $8 \%$ \\
\hline Sofijska & 4 & 3 & 13 & 2.897 & 570 & 38.372 & $14 \%$ & $10 \%$ \\
\hline Zagrebačka & 7 & 90 & 14 & 3.966 & 400 & 41.501 & $3 \%$ & $37 \%$ \\
\hline Skopska & 23 & 0 & 128 & 15.533 & 34 & 7.406 & $2 \%$ & $21 \%$ \\
\hline Montenegro & 1 & 29 & 86 & 1.585 & 13 & 3.166 & $1 \%$ & $41 \%$ \\
\hline Ljubljanska & 4 & 18 & 0 & 1.313 & 299 & 34.726 & $6 \%$ & $15 \%$ \\
\hline
\end{tabular}

Table 1: Performances of Southeast European Stock Exchanges

[Source: Stock exchanges' web sites and annual reports, prepared by authors]

to them too: small number of officially listed companies, insufficient market capitalisation and, the by far the most important of them all, low liquidity. Liquidity is the single most solid indicator of the state of some of the stock markets. Low liquidity markets exert strong limitations on investors which results in low demand for portfolio investors and very small volume of investments in such economies. In addition to macroeconomic limiting factors, there are also other limitations resulting from non-transparent business operations of listed companies, distrust in the quality and accuracy of financial statements and loss of confidence on the part of investors during the financial crisis. There are several cases of listed companies which, following the fast rising during the period of growth, recorded dramatic worsening of business performance and entered into restructuring or even bankruptcy proceedings. In such cases, it was often revealed that their financial statements were of poor quality, with elements of fraud. Therefore, improving the quality of the overall reporting system, including quality of accounting regulations, auditing and of financial control is the key assumption and the foundation for development of financing method based on issue of shares and corporate bonds. Companies listed on these stock exchanges need to significantly improve the quality of reporting and also to include non-financial reporting which will provide investors with information regarding other important business segments, such as: corporate social responsibility and efficient energy use. In this sense, the stock exchanges themselves should make additional efforts to include these non-financial criteria in the requirements which the companies must meet to be listed, as is common practice for many developed stock exchanges. [9]

Having in mind the significance of developing alternative markets with the aim to strengthen stock exchange and securities market, preparation of the proposals which may bring this about is currently underway in the European Union. Among other things, Federation of European Stock Exchanges [10] proposed a goal according to which market capitalisation of each country should match its GDP. If such recommendation were to be adopted, Serbia would be faced with a highly unattainable objective since its share of market capitalisation in GDP is meagre $10 \%$, accompanied with low market liquidity.

\section{CONCLUSION}

Financial market of the European Union is oriented towards banking sector unlike US financial market. Absence of competition in financing companies through stock/bond issues results in higher interest rates that affect their over-indebtedness which in return results in even higher interest rates. Improving the quality of financial reporting based on regulations and practices applied in EU countries and implementation of international accounting standards would certainly contribute to development of capital market. Analysed Southeast European stock exchanges fall significantly behind those operating on the developed market, so necessary measures should be taken to improve capital market. The process of accession of Serbia to European Union also requires significant improvements in this market segment which is, measured by market capitalisation to GDP ratio, highly underdeveloped.

\section{REFERENCES}

[1] Bodie, Z, Kane,A, Marcus, A, INVESTMENTS, McGraw Hill, USA, 2014.

[2] Jeremic, Z, Finansijska tržišta i finansijski posrednici, Univerzitet Singidunum, Beograd, 2012.

[3] Alibaba IPO ranks as words biggest IPO after additional shares sold, http://reuters.com

[4] http://www.nasdr.com

[5] 2013. WFI Market highlights, 24.01.2014, p.1)

[6] The Transparency for Listed Companies Directive 2004/109/ EC

[7] Regulation (EC) No 1606/2002 of the European parlament and of the council of 19 July 2002 on the application of international accounting standards

[8] COMMISSION REGULATION (EC) No 1126/2008 of 3 November 2008. adopting certain international accounting standards in accordance with Regulation (EC) No 1606/2002 of the European Parliament and of the Council

[9] European Exchange Report 2013, [available on site http:// www.fese.eu]

[10] Blueprint for European Capital market-how to unleash markets potencial to finance dynamic and sustainable growt, dostupno na http://www.fese.eu

\title{
FINANSIJSKO IZVEŠTAVANJE KOMPANIJA LISTIRANIH NA BERZAMA U EVROPSKOJ UNIJI I JUGOISTOČNOJ EVROPI
}

\author{
Zoran Jeremić1 ${ }^{1}$ Ivica Terzić ${ }^{2}$ \\ ${ }^{1}$ Poslovni fakultet u Beogradu, Univerzitet Singidunum, Danijelova 32, Beograd, Srbija, zjeremic@singidunum.ac.rs \\ ${ }^{2}$ Poslovni fakultet u Beogradu, Univerzitet Singidunum, Danijelova 32, Beograd, Srbija, iterzic@singidunum.ac.rs
}

\section{Apstrakt:}

Ovaj članak bavi se uslovima koje listirane kompanije treba da ispune ukoliko su kotirane na nekoj od berzi u Evropskoj uniji. U radu je navedena regulativa EU kao i računovodstveni standardi vezani za ovu oblast. Posebna pažnja posvećena je stanju na tržištu kapitala i finansijskom izveštavanju na berzama Jugoistočne Evrope, da bi se utvrdio stepen usklađenosti sa regulativom EU. Sprovedeno je istraživanje o regulativi i listiranim kompanijama na berzama u zemljama ovog regiona da bi se sagledao položaj tržišta kapitala Srbije i listiranih kompanija na Beogradskoj berzi u odnosu na region. $\mathrm{Na}$ kraju rada date su preporuke za poboljšanje stanja u ovoj oblasti.

\section{Ključne reči:}

listirane kompanije, berza, računovodstveni standardi. 